\title{
Tradisi Ziarah Makam Bathara Katong (Tinjauan Deskripsi Akulturasi Budaya)
}

\author{
Amirul Nur Wahid ${ }^{1}$, Sumarlam ${ }^{2}$, Slamet Subiyantoro ${ }^{3}$ \\ ${ }^{1,2,3}$ Program Pascasarjana, Universitas Sebelas Maret Surakarta
}

amxito@gmail.com

\begin{abstract}
Masyarakat Jawa, tak terkecuali masyarakat Ponorogo seringkali memiliki kebiasaan-kebiasaan tertentu yang dilakukakan. Kebiasaan-kebiasaan ini diwariskan secara turun temurun hingga menjadi sebuah tradisi. Tradisi ziarah makam Bathara Katong merupakan salah satunya. Tradisi ini dilakukan oleh masyarakat Ponorogo dan sekitarnya sejak zaman dahulu. Bathara Katong merupakan tokoh sentral dalam penyebaran agama Islam. Pada saat itu terjadi transisi antara agama lama dan baru dari segala aspek. Transisi inilah yang menjadikan akulturasi budaya diantara kedua hal tersebut. Akulturasi budaya ini juga merambah bidang kesenian di area sekitar makam, misalnya munculnya kesenian Jemblung yang merupakan akulturasi antara dua kebudayaan menjadi satu. Selain kesenian, akulturasi juga dapat ditemukan di arsitektur bangunan-bangunan, proses ziarah, serta benda-benda yang dibawa oleh peziarah makam Bathara Katong. Nama Bathara Katong sendiri sebenarnya merupakan sebuah akulturasi kebudayaan. Hanya saja dikarenakan mengikuti perkembangan zaman, tradisi ini juga mengalami perubahan-perubahan dalam akulturasinya. Artikel ini akan mencoba mengupas hal tersebut.
\end{abstract}

Kata kunci : akulturasi, jawa, budaya, bathara katong

\section{The Pilgrimage Tradition of Bathara Katong Tomb (A Brief Overview of a Cultural Acculturation)}

Javanese are no exception Ponorogo people have certain habits. This habit is passed down from generation to generation and then becomes a tradition. The pilgrimage tradition of Bathara Katong's tomb is one of them. This tradition is done by the people of Ponorogo and its surroundings since antiquity. Bathara Katong is a central figure in the spread of Islam in Ponorogo. There was a transition between old and new cultures from various aspects. This transition is considered to be the cause of cultural acculturation. Acculturation of this culture also penetrated the field of art in the area around the tomb, for example the emergence of art Jemblung which is the acculturation between two cultures into one. In addition to art, acculturation can also be found in the architecture of the building, the process of pilgrimage, and the objects brought by the pilgrims of the tomb of Bathara Katong. The name Bathara Katong itself is actually an example of cultural acculturation. Just because it follows the times, this tradition has also changed. This article will try to explore it.

Keywords : acculturation, java, culture, bathara katong

Proses Review : 1 - 31 Maret 2018, Dinyatakan Lolos: 10 April 2018 


\section{PENDAHULUAN}

Perselisihan antar kebudayaan yang sedang marak-maraknya di Indonesia saat ini membuat banyak kalangan bergejolak. Kurangnya toleransi ditengarai merupakan salah satu penyebab terjadinya hal tersebut. Padahal sejak jaman dahulu masyarakat Indonesia sudah seringkali didatangi dan toleran terhadap kebudayaan-kebudayaan baru. Sebagai contoh, datangnya ajaran Hindu-Budha ke Pulau Jawa disambut oleh masyarakat Jawa. Hal ini tentunya menarik dikarenakan masyarakat Jawa pada saat itu sudah memiliki kepercayaan mereka sendiri. Walaupun begitu masyarakat tetap menerima datangnya kebudayaan baru. Bahkan, lama-kelamaan kita mengetahui banyak kebudayaan Jawa yang dipengaruhi oleh corak kebudayaan Hindu-Budha. Datangnya kebudayaan baru justru memperkaya kebudayaan yang sudah ada. Tak terkecuali saat ajaran Islam mulai memasuki Pulau Jawa. Kebudayaan yang datang diterima tanpa menghilangkan kebudayaan yang lama, bahkan terjadi akulturasi budaya diantara kedua kebudayaan.

Akulturasi merupakan proses sosial yang timbul bila suatu kelompok manusia dengan suatu kebudayaan tertentu dihadapkan dengan unsur-unsur dari suatu kebudayaan asing dengan sedemikian rupa, sehingga unsur-unsur kebudayaan asing itu lambat laun diterima dan diolah ke dalam kebudayaan sendiri tanpa menyebabkan hilangnya kepribadian kebudayaan itu sendiri (Koentjaraningrat, 2009: 202). Proses akulturasi antara kebudayaan-kebudayaan yang satu dengan yang lain tentunya membutuhkan waktu yang tidak sebentar. Hal ini senada dengan pernyataan Koentjaraningrat dalam Sulasman (2013: 12-13) yang menyatakan bahwa sistem religi atau upacara keagamaan merupakan unsur universal kebudayaan yang susah untuk berubah dan susah untuk dipengaruhi oleh kebudayaan lain. Sebuah tradisi yang dilakukan oleh masyarakat Jawa, misalnya tradisi ziarah makam Bathara Katong ditengarai merupakan salah satu tradisi yang mengandung akulturasi antar kebudayaan.

Tradisi berarti suatu warisan yang turun-temurun dilakukan oleh masyarakat. Proses pewarisannya dilakukan secara berulang-ulang dalam bentuk yang sama (Soekanto, 1990: 181). Tradisi ziarah makam Bathara Katong merupakan kegiatan yang dilakukan secara berulang-ulang dan turun temurun oleh masyarakat dari Ponorogo ataupun dari luar Ponorogo. Walaupun sama-sama termasuk ke dalam upacara adat Jawa, tradisi ini sedikit berbeda dengan nyadran. Hal ini disebabkan karena tradisi ini dapat dilakukan setiap saat. Nyadran adalah rangkaian kegiatan yang dilakukan oleh orang Jawa setahun sekali dalam rangka mendoakan para leluhur yang telah tiada agar mendapatkan tempat yang layak disisi Tuhan (Bayuadhy, 2015: 97-98). Walaupun berbeda, di dalam kedua proses tradisi sama-sama terdapat tradisi nyekar. Nyekar merupakan adat untuk mengunjungi makam. Adat ini mer- upakan aktivitas yang sangat penting menurut sistem religi masyarakat Jawa (Koentjaraningrat, 1984: 363). Nyekar dilakukan dengan cara menaburkan bunga-bunga tertentu di atas makam.

Tradisi ziarah makam Bathara Katong dilakukan untuk menghormati atau mengenang sosok Bathara Katong. Bathara Katong merupakan sosok penting dalam pendirian serta penyebaran agama Islam di Ponorogo. Beliau merupakan anak Raja Brawijaya dari Kerajaan Majapahit dan adik Raden Patah, Raja Kerajaan Demak yang pertama (Moelyadi. 1986: 127). Bathara Katong mempunyai nama asli Raden Katong. Beliau mendapatkan gelar "Bathara" karena kesaktiannya. Kesaktiannya diibaratkan setara dewa. Kata Bathara sendiri memiliki arti "Dewa". Kesaktian Bathara Katong inilah yang berhasil menandingi kesaktian Ki Ageng Kutu. Ki Ageng Kutu merupakan penguasa daerah Ponorogo sebelumnya. Juru Kunci Makam Bathara Katong menyebut Bathara Katong dengan sebutan Eyang atau kakek.

Pelaksanaan tradisi ziarah ke makam Bathara Katong dapat dilakukan setiap saat. Hanya saja kebanyakan peziarah makam memilih waktu pada hari Jum'at. Satu bulan sebelum tanggal 1 Sura merupakan puncak kedatangan peziarah makam. Khusus pada tanggal 1 Sura dan pada hari jadi Kabupaten Ponorogo, segenap jajaran Pemerintah Daerah Kabupaten Ponorogo (termasuk Bupati Ponorogo) melakukan tradisi ziarah makam bersama. Tradisi ziarah makam Bathara Katong merupakan salah satu agenda rutin dalam kegiatan Kirab Pusaka. Pusaka yang berada di Kota Baru dibawa ke Makam Bathara Katong pada malam hari. Kegiatan ini diikuti oleh segenap Pemerintah Kabupaten Ponorogo beserta masyarakat dari berbagai golongan. Pusaka Kabupaten Ponorogo tersebut diserahkan oleh Bupati kepada Juru Kunci Makam dan diletakkan di depan Makam Bathara Katong sampai siang. Siangnya, Pusaka tersebut diserahkan kembali kepada Bupati, kemudian dibawa kembali ke tempat asalnya.

Sebuah tradisi seringkali mencerminkan simbol persatuan kebudayaan. Corak dinding bangunan makam Bathara Katong misalnya. Kita dapat menemukan adanya perpaduan antara kebudayaan lama dan kebudayaan baru. Terdapat panji/lambang/bendera Majapahit dalam ukiran di dinding tersebut yang mencerminkan kebudayaan lama, serta adanya corak Demak yang mencerminkan kebudayaan Islam. Kedua corak tersebut terpadu menjadi satu dan menjadi sebuah karya seni yang melambangkan persatuan antara kebudayaan. Artikel ini bertujuan untuk menggambarkan hal-hal lainnya yang berkaitan dengan akulturasi budaya dalam tradisi ziarah makam Bathara Katong.

\section{METODE PENELITIAN}

Penelitian ini menggunakan jenis penelitian deskriptif kualitatif. Menurut Arifin (2011: 140), penelitian kualitatif 
adalah suatu proses penelitian yang dilakukan secara wajar dan natural sesuai dengan kondisi obyektif di lapangan tanpa adanya manipulasi. Deskriptif kualitatif digunakan untuk menggambarkan akulturasi budaya yang ada di dalam tradisi ziarah makam Bathara Katong baik di masa lalu maupun masa sekarang. Peneliti akan menjadi instrumen kunci penelitian dengan mengamati secara langsung proses tradisi ziarah makam Bathara Katong baik di masa lalu maupun masa sekarang. Peneliti sendirilah yang akan menjadi instrumen kunci untuk mengumpulkan data yang terkait dengan tujuan penelitian.

Cara yang digunakan adalah melalui metode observasi dan wawancara mendalam. Observasi adalah pengamatan akan manusia pada habitatnya (Hughes dalam Sarosa, 2012: 56). Metode observasi digunakan untuk menggambarkan proses, bangunan, dan benda-benda yang ada dalam tradisi ziarah makam Bathara Katong. Peneliti mengacu pada data pada lembar observasi untuk membuat pertanyaan-pertanyaan dalam wawancara mendalam dengan informan. Informan dalam penelitian ini meliputi Juru Kunci Makam, Sesepuh, Peziarah Makam, dan Warga Sekitar Makam. Data yang diperoleh dalam observasi ini masih merupakan data lunak, karena data tersebut masih akan diolah lebih lanjut (Rahmat, 2009: 8). Hasil data observasi dalam penelitian ini juga memuat gambar-gambar yang berhubungan dengan tradisi ziarah makam Bathara Katong. Pengambilan foto dilakukan karena memerlukan waktu yang singkat. Waktu yang singkat dalam mengambil data diharapkan tidak akan mengganggu kekhusyukan peziarah makam. Pengambilan data video urung dilakukan setelah mendapat nasehat dari mayoritas kalangan Peziarah Makam setelah dilakukan wawancara.

Peneliti selain mengambil data dengan observasi juga menggunakan teknik wawancara mendalam. Wawancara mendalam menurut Sutopo(2002: 59) adalah teknik yang dilakukan untuk mengumpulkan data dalam penelitian kualitatif. Pengambilan data dalam teknik wawancara mendalam dilakukan secara santai, akan tetapi tetap memperhatikan tujuan yang hendak dicapai. Tujuan penelitian ini tentunya adalah mengungkap akulturasi budaya dalam tradisi ziarah makam Bathara Katong. Wawancara dilakukan kepada Juru Kunci Makam, Sesepuh, Peziarah Makam, dan Masyarakat di sekitar makam. Wawancara dengan Peziarah Makam dan warga sekitar makam akan dilakukan secara acak.

Teknik lain yang digunakan peneliti untuk melengkapi teknik wawancara adalah teknik dokumentasi. Menurut Yin dalam Sutopo (2002: 69-70) teknik dokumentasi merupakan teknik mencatat isi penting yang tersurat dalam dokumen atau arsip, dan memahami makna yang tersirat di dalamnya. Peneliti mencatat data dalam buku-buku serta dokumen-dokumen lainnya yang berkaitan dengan fokus penelitian ini, yaitu akulturasi budaya dan tradisi ziarah makam, serta Bathara Katong.
Penelitian ini menggunakan strategi penelitian studi kasus tunggal terpancang. Menurut Sutopo (2002: 112-113), studi kasus tunggal adalah penelitian ini akan mengarah pada satu karakteristik sasaran dan terpancang adalah fokus pada tujuan penelitian. Jadi, studi kasus tunggal terpancang berarti penelitian akan mengarah pada satu karakteristik dan fokus pada tujuan penelitian. Fokus penelitian ini tentu saja mengarah pada akulturasi budaya dalam tradisi ziarah makam Bathara Katong. Selain itu, penelitian ini juga akan sedikit mendeskripsikan gambaran umum tradisi ziarah makam Bathara Katong.

Data yang telah dikumpulkan dalam beberapa teknik di atas selanjutnya dianalisis melalui tahapan reduksi data, penyajian data, pengambilan kesimpulan. Analisis data yang digunakan adalah analisis induktif. Menurut Muhadjir(2002: 167) adalah analisis data spesifik yang didapatkan dari lapangan, dibagi dalam unit-unit, kemudian dijadikan kategori-kategori tersendiri. Terakhir, peneliti menggunakan teknik triangulasi sumber dan metode untuk mengesahkan data.

\section{ANALISIS DAN INTEPRETASI DATA}

Situs tradisi ziarah makam Bathara Katong terletak di Kelurahan Setono, Kecamatan Ponorogo, Kabupaten Ponorogo, Provinsi Jawa Timur. Tempat ini merupakan salah satu tempat di bawah naungan Balai Pelestarian Cagar Budaya Jawa Timur. Area makam Bathara Katong terletak di tengah-tengah pemukiman penduduk. Tradisi ziarah makam Bathara katong sendiri dapat dilakukan setiap saat, akan tetapi para peziarah seringkali memiliki hari-hari tertentu untuk melakukan tradisi tersebut. Hari Jum'at merupakan hari yang dianggap paling baik. Seringkali peziarah melakukan tradisi pada hari ini. Pintu gerbang makam Bathara Katongpun dibuka untuk umum pada hari ini. Peziarah yang bermaksud untuk berziarah makam di hari yang lain harus menghubungi Juru Kunci Makam terlebih dahulu.

Menurut penuturan Juru Kunci Makam, puncak kedatangan peziarah terjadi pada satu bulan sebelum bulan Sura dan beberapa hari di awal bulan Sura. Tanggal 1 Sura merupakan hari yang fenomenal, dikarenakan pada tanggal ini pula Bupati Ponorogo beserta jajaran Pemerintah Daerah Kabupaten Ponorogo dan masyarakat Ponorogo dari berbagai kalangan melakukan tradisi ziarah makam Bathara Katong bersama-sama. Pada hari itu makam Bathara Katong akan dipenuhi dengan dekorasi-dekorasi khas kejawen yang meliputi umbul-umbul dari janur kuning, Acara tradisi ziarah makam merupakan salah satu dari agenda rutin tahunan Grebeg Sura. Tradisi ziarah makam sendiri merupakan bagian dari Kirab Pusaka Ponorogo. Kirab Pusaka dimulai dengan membawa Pusaka dari Pusat Pemerintahan menuju Kota Lama. Setelah sampai di makam Bathara Katong, Pusaka tersebut kemudian diserahkan kepada Juru Kunci Makam. Puasa kemudian diinapkan 


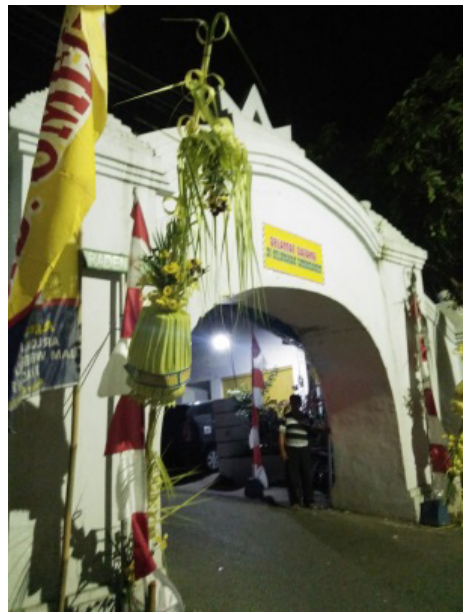

Gambar 1. Gerbang Pertama Makam Bathara Katong (Dok. Amirul, 2017)

selama semalam di depan makam Bathara Katong. Pada siang harinya Pusaka diserahkan kembali kepada Bupati Ponorogo oleh Juru Kunci Makam. Selain itu, tradisi ziarah makam Bathara Katong secara bersama-sama juga dilakukan pada tanggal 11 Agustus. Masyarakat Ponorogo percaya bahwa pada tanggal ini Bathara Katong secara resmi dilantik menjadi Adipati Ponorogo yang pertama. Sehingga bisa dikatakan bahwa tanggal 11 Agustus merupakan hari jadi Kabupaten Ponorogo.

Peziarah Makam Bathara Katong tidak hanya didominasi oleh laki-laki, akan tetapi banyak pula peziarah yang berkelamin perempuan. Tidak ada batasan usia dalam melakukan tradisi ziarah ini. Tidak hanya dilakukan oleh orang dewasa saja, tetapi anak-anak juga banyak yang datang untuk berziarah makam. Walaupun ziarah yang dilakukan masih dalam tahap pembelajaran.

"Pengunjung makam ini beragam, dari laki-laki dan perempuan. Perempuan yang sedang halangan diperbolehkan masuk sampai depan gerbang kelima. Anak-anak diperbolehkan masuk untuk pembelajaran mengenai leluhur."

Menurut penuturan Juru Kunci Makam di atas, perempuan yang sedang berhalangan (menstruasi) tidak diperkenankan memasuki makam Bathara Katong. Sebenarnya boleh memasuki area makam, hanya saja sampai ke depan gerbang kelima saja. Apabila menyalahi aturan tersebut dikhawatirkan akan mendapatkan hal-hal yang kurang baik, selain itu menaati peraturan tradisi ini juga merupakan wujud penghormatan kepada Bathara Katong.

Bathara Katong sendiri dulunya hidup ditengah-tengah masa transisi antara kebudayaan lama dan baru, sehingga bangunan-bangunan peninggalan pemerintahannya mengandung kepaduan antara dua kebudayaan, tak terkecuali makamnya. Akulturasi budaya pada tradisi ziarah makam Bathara Katong sendiri dapat ditemukan pada bangunan-bangunan yang ada di area makam Bathara Katong, pada benda-benda yang dibawa oleh peziarah, pada proses

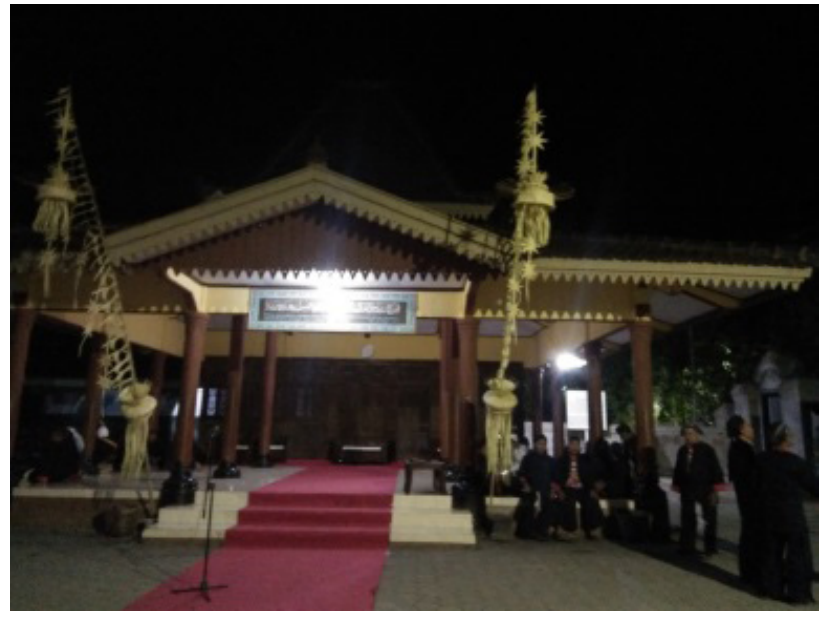

Gambar 2. Pendapa Makam Bathara Katong (Dok. Amirul, 2017)

tradisi, serta pada kesenian yang berkembang di area sekitar makam.

Pertama, akulturasi pada bangunan-bangunan di area makam Bathara Katong. Bangunan yang pertama ditemui tentunya adalah gerbang makam Bathara Katong. Gerbang tersebut berjumlah tujuh buah. Ada gerbang yang dicat adapula yang tidak. Ada yang berdaun pintu ada pula yang tidak berdaun pintu.

"Gerbang-gerbang di Makam Bathara Katong berjumlah tujuh buah. Angka tujuh dalam bahasa Jawa disebut pitu. Pitu merupakan penggalan dari kata pitulungan yang berarti pertolongan. Dengan melewati ketujuh gerbang, diharapkan peziarah akan mendapatkan pertolongan dari Tuhan Yang Maha Esa. Angka tujuh juga melambangkan kata lailahailallah yang berarti tidak ada Tuhan selain Allah." Menurut pernyataan Juru Kunci di atas, ketujuh gerbang makam Bathara Katong menggambarkan pandangan dari sudut pandang Islam maupun Kejawen. Pada intinya maksudnya sama, yaitu untuk mencapai kesempurnaan hidup manusia harus selalu menjalankan perintah dan menjauhi larangan-Nya. Selain dari jumlah, gerbang-gerbang makam tersebut juga dapat dicermati dari dari segi desainnya.

Gerbang Makam Bathara Katong di atas dipengaruhi oleh arsitektur Gapura Candi Bentar. Gapura Candi Bentar adalah desain yang dipengaruhi oleh kebudayaan Hindu, desain ini biasanya ditemukan pada arsitektur bangunan-bangunan pada kompleks Kerajaan Majapahit (Zarifa, 2017: 383). Gapura ini merupakan bentuk akulturasi antara kebudayaan kerajaan Majapahit dan kebudayaan Islam. Warna putih yang dipilih menggambarkan kesucian. Cat pada bangunan ini masih bagus dan tidak kusam. Kondisi gerbang gapura makam Bathara Katong inipun masih bisa dikatakan terawat dengan baik. Hal ini tentunya tidak terlepas dari peran Juru Kunci Makam yang senantiasa merawat bangunan tersebut. 


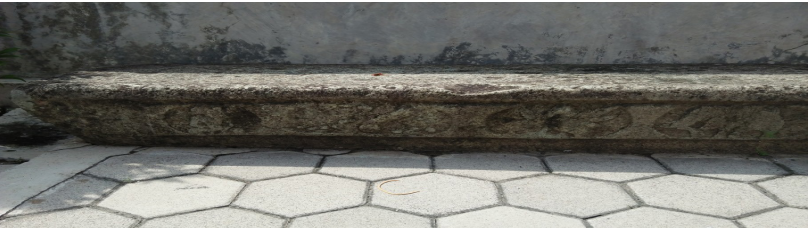

Gambar 3. Prasasti di Makam Bathara Katong (Dok. Amirul, 2017)

Bangunan kedua yang dapat ditemukan adalah Pendapa Makam. Pendapa ini terletak di depan gerbang/gapura makam yang kelima. Pada hari-hari biasa, pendapa ini digunakan sebagai tempat singgah peziarah sebelum memasuki area makam yang lebih dalam. Saat tanggal 1 Sura, keadaannya akan berbeda. Pendapa akan didekorasi sedemikian rupa, kemudian digunakan oleh Bupati sebagai tempat singgah sementara sebelum upacara penerimaan kembali Pusaka Kabupaten Ponorogo. Bangunan pendapa ini berbentuk Joglo terbuka. Arsitektur pendapa yang merupakan ciri khas kebudayaan masyarakat Jawa masih digunakan disini.

Gambar 3 menunjukkan sebuah prasasti. Letaknya di depan gerbang kelima dan keenam. Juru Kunci Makam menyebut prasasti tersebut sebagai Watu Gilang. Prasasti tersebut menunjukkan angka tahun. Angka tahun ditunjukkan oleh gambar manusia yang bertapa, pohon, burung garuda, dan gajah. Prasasti yang menandakan angka tahun seperti ini disebut sengkalan atau candra sengkala. Sengkalan menurut Suwito(2006: 8) berarti angka taun yang dilambangkan dengan kalimat, gambar atau ornamen tertentu. Sengkalan yang berlukiskan gambar-gambar disebut sengkalan memet. Sengkalan memet menurut Macaryus(2007: 201) adalah sengkalan yang secara visual diwujudkan dalam bentuk gambar. Berdasarkan penuturan Juru Kunci makam, gambar orang bersemedi menggambarkan angka 1, kemudian gambar pohon menggambarkan angka 4. Gambar burung garuda merupakan perwujudan angka 1, dan gambar gajah perwujudan angka 8. Jika dirangkai, gambar tersebut akan menunjukkan tahun 1418 Saka atau tahun Jawa atau 1496 Masehi. Pada tahun ini dipercaya bahwa Bathara Katong dinobatkan sebagai adipati Ponorogo yang pertama yang kemudian diperingati sebagai hari jadi kota Ponorogo setiap tahunnya. Prasasti seringkali ditemukan pada peninggalan-peninggalan kerajaan yang bercorak Hindu-Budha. Hal ini tentunya unik dikarenakan prasasti ternyata juga ditemukan di makam Bathara Katong yang notabenenya adalah pengikut ajaran agama Islam. Menurut penuturan Juru Kunci Makam, prasasti ini pada zaman dahulu mempunyai dua fungsi selain sebagai penanda angka tahun. Pertama, sebagai tempat bersemedi Bathara Katong. Kedua, sebagai alas sholat Bathara Katong. Hal ini tentunya menunjukkan adanya akulturasi kedua kebudayaan disini.

Corak ukiran di dinding makam Bathara Katong bagian atas merupakan corak bunga teratai. Corak bunga teratai
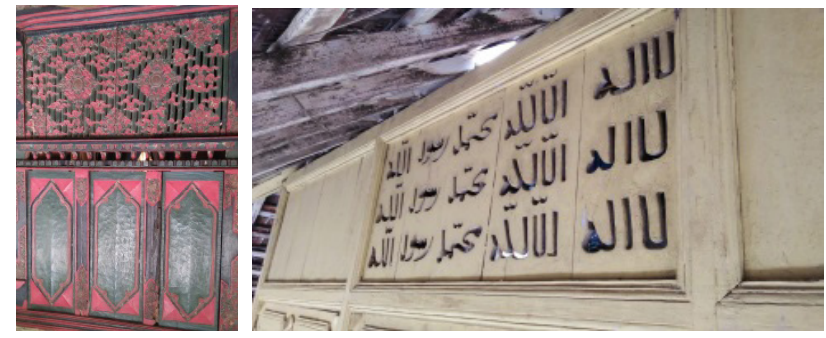

Gambar 3. Ukiran dinding Makam Bathara Katong

(Dok. Amirul, 2017)

merupakan corak yang seringkali digunakan dalam panji-panji Kerajaan Majapahit. Bagian bawah dari corak di dinding makam tersebut berupa perisai segi enam yang jamak ditemukan pada bangunan-bangunan Islam pada masa itu. Keterpaduan kedua corak ini menandakan akulturasi atau perpaduan diantara kedua kebudayaan yang mempengaruhi kebudayaan masyarakat Ponorogo. Selain corak bunga teratai dan perisai, terdapat pula ukiran yang bertuliskan lailahaillallah muhammaddar rasullullah yang sangat kental menunjukkan adanya kebudayaan Islam di sini.

Akulturasi yang selanjutnya dapat ditemukan pada benda-benda yang dibawa oleh peziarah makam Bathara Katong. Benda yang pertama adalah bunga. Bunga seringkali dibawa oleh peziarah saat melakukan tradisi ziarah makam Bathara Katong. Berdasarkan jumlah bunganya, dapat dikelompokkan menjadi dua macam. Pertama, bunga telon yang biasanya terdiri dari tiga macam jenis bunga, misalnya: bunga mawar, bunga melati, dan bunga kantil. Bisa juga terdiri atas bunga mawar merah, bunga mawar putih, dan bunga kenanga. Bunga telon menurut Anggrahita dan Sunarto (2016: 12) mencerminkan tempat yang tinggi yang juga bisa diartikan kekuasaan Tuhan Yang Maha Esa. Dengan membawa bunga telon diharapkan agar doa yang dipanjatkan peziarah sampai ke tempat Tuhan. Selain kembang telon, banyak pula peziarah yang membawa jenis bunga setaman. Bunga setaman menurut Pradanda, Sudardi, dan Subiyantoro (2015: 165) adalah berbagai macam bunga yang tumbuh di taman. Jenisnya pun tidak hanya terpaku pada satu jenis bunga. Susunan bunga setaman sendiri biasanya terdiri atas bunga mawar merah, bunga mawar putih, bunga kantil, bunga melati, dan bunga kenanga. Kadang-kadang ada pula peziarah yang menambahkan susunan bunganya dengan bunga sedap malam atau melati gambir.

Kedua jenis bunga di atas digunakan dalam proses tradisi nyekar. Nyekar adalah kegiatan menaburkan bunga di atas makam. Tradisi nyekar sebenarnya sudah ada sebelum kedatangan agama Islam. Sebagian masyarakat Jawa berkeyakinan, mengirim pahala bacaan doa dalam tradisi nyekar bukan saja bertujuan agar arwah orang yang telah meninggal memperoleh tempat yang baik di surga, tetapi juga mendatangkan pahala bagi pengirim doa itu sendiri (Toha, 2016: 194). Selain opsi kedua jenis bunga di atas, 


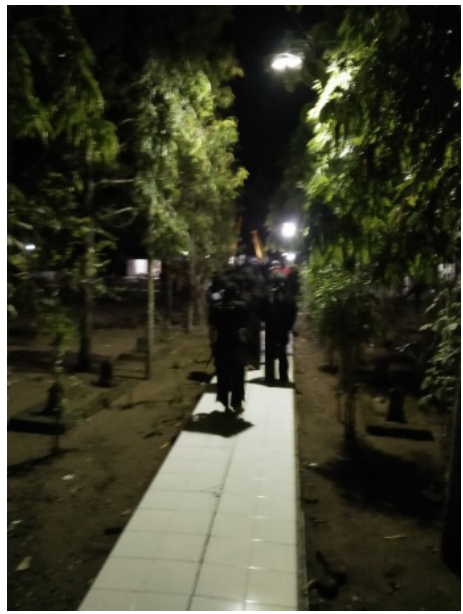

Gambar 4. Perjalanan melewati Gerbang (Dok. Amirul, 2017)

peziarah makam juga diperbolehkan membawa bunga yang berwarna putih saja, misalnya bunga mawar putih, melati, dan kantil. Bisa juga membawa salah satu saja kalaupun memang tidak bisa membawa ketiganya. Bunga yang berwarna putih mencerminkan niatan peziarah yang suci, tulus, dan ikhlas dalam melaksanakan tradisi ziarah makam Bathara Katong. Apabila melengkapi semua bunganya bisa dikatakan punya nilai lebih karena mencerminkan kesungguhan niat peziarah dalam mencari ubarampe atau perlengkapan tradisi ziarah makam Bathara Katong.

Ada yang perlu diperhatikan dalam campuran bunga-bunga yang dibawa oleh peziarah. Peziarah tidak diperkenankan mencampurkan daun pandan wangi ke dalam bunga-bunganya. Campuran yang diperbolehkan adalah boreh saja. Pandan wangi dipercaya merupakan senjata dari Ki Ageng Kutu, sehingga Bathara Katong kurang begitu menyukainya. Peziarah yang mencampurkan daun pandan wangi dalam bunga-bunga yang dibawanya dikhawatirkan akan tidak tercapai niat yang diinginkannya.

Benda kedua yang seringkali dibawa atau disiapkan oleh pengunjung adalah dimik atau yuspa dan menyan. Kedua benda ini digunakan dengan cara dibakar. Dimik berbentuk seperti lidi yang panjang dan apabila dibakar akan menimbulkan wangi-wangi tertentu. Pembakaran dimik seringkali dilakukan oleh masyarakat Tionghoa atau Hindu-Budha dalam upacara keagamaannya. Penggunaan dimik dalam tradisi ziarah makam Bathara Katong adalah sebagai wewangian. Selain dimik, menyan juga dibakar untuk mendapatkan aroma yang harum. Peziarah makam akan berdoa setelah sesaat sebelumnya menyalakan dimik dan menyan. Asap yang dihasilkan oleh dimik dan menyan yang membumbung tinggi diharapkan dapat menjadi perantara antara yang dibawah (peziarah yang sedang berdoa) dengan yang di atas (Tuhan Yang Maha Esa).

Benda ketiga yang kadangkala dibawa oleh peziarah adalah minyak Serimpi atau Pambo. Minyak ini berfungsi

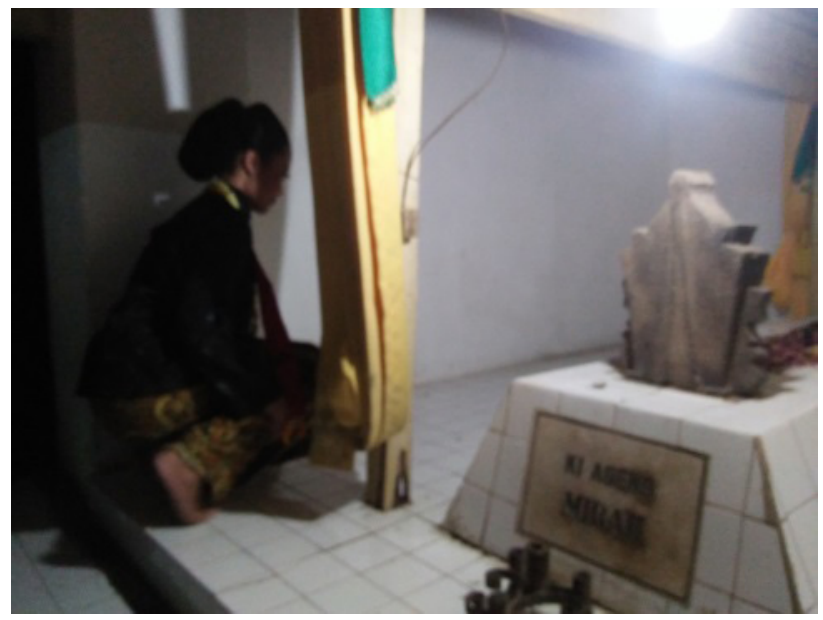

Gambar 5. Peziarah Makam yang melakukan laku dhodhok (Dok. Amirul, 2017)

sama yaitu sebagai wewangian. Hanya saja penggunaannya dilakukan dengan cara dioleskan ke tubuh atau pakaian peziarah makam. Tubuh dan pakaian yang wangi dan bersih merupakan salah satu bentuk kesopanan dan penghormatan kepada leluhur. Bau harum yang ditimbulkan juga akan menimbulkan kenyamanan bagi peziarah yang lain. Memakai wewangian sendiri merupakan salah satu hal yang disunahkan dalam agama Islam.

Akulturasi budaya yang ketiga ditemukan pada proses tradisi ziarah makam Bathara Katong. Proses tradisi ziarah makam Bathara Katong melalui beberapa tahap, yaitu: menemui Juru Kunci makam, menyiapkan ubarampe, berjalan melewati gapura-gapura makam, bersuci, membakar dimik dan menyan, dan berdoa. Proses pertama dalam tradisi ziarah makam Bathara Katong adalah menemui Juru Kunci Makam untuk uluk salam dan membuat kesepakatan kapan akan dilakukannya tradisi ziarah. Sesudah disepakati waktunya, peziarah menyiapkan ubarampe atau perlengkapan tradisi ziarah.

Tahap selanjutnya adalah berjalan melewati gapura-gapura makam. Perjalanan ini untuk membuktikan kesungguhan niat dari peziarah makam. Pada masa lalu proses berjalan kaki ini dimulai dari gerbang pertama sampai ketujuh. Hanya saja dikarenakan perkembangan zaman. Perjalanan ini sekarang dimulai dari gerbang ketiga. Bahkan motor sudah bisa masuk sampai ke depan gerbang kelima. Pada masa lalu pula setelah memasuki gerbang kelima, peziarah dianjurkan untuk melakukan laku dhodhok. Hanya saja proses ini sekarang sudah jarang sekali dilakukan para peziarah. Kalaupun ada, proses laku dhodhok hanya dilakukan peziarah saat memasuki bangunan makam utama saja. Kalangan peziarah yang melakukan laku dhodhok inipun terbatas dari peziarah yang berasal dari Kraton Solo dan Kraton Jogja saja.

Peziarah yang akan memasuki gapura makam yang kelima dianjurkan untuk bersuci terlebih dahulu dikarenakan di 


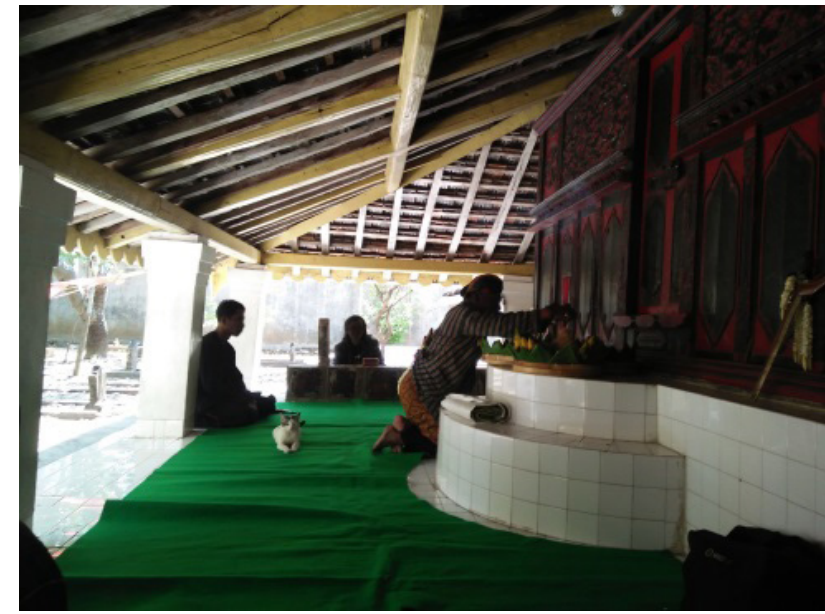

Gambar 6. Peziarah sedang membakar dimik (Dok. Amirul, 2017)

balik gerbang kelima merupakan kompleks makam Sentono Dalem Kabupaten Ponorogo. Perempuan yang berhalangan dipersilahkan istirahat di depan pintu gerbang kelima. Tepatnya di pendapa Bathara Katong, selain itu di sini juga terdapat bangunan Masjid Jami' Bathara Katong. Proses tradisi selanjutnya adalah berjalan sampai ke bangunan utama makam Bathara Katong. Pada bangunan utama ini kadangkala peziarah makam melakukan proses laku dhodhok.

Laku dhodhok merupakan wujud penghormatan terhadap orang yang dihormati, dalam hal ini adalah leluhur yang dikebumikan di tempat tersebut. Proses selanjutnya adalah berdoa berdasarkan kepercayaan masing-masing. Ada peziarah yang berdoa menggunakan cara Islami disertai tahlilan adapula yang secara Kejawen.

Terlihat pada gambar 6 , peziarah yang melakukan doa dengan cara kejawen membakar kemenyan terlebih dahulu. Namun ada pula peziarah yang berdoa secara Islami juga melakukan proses ini terlebih dahulu. Proses ini diawali dengan membakar sungkem lalu membakar dimik kemudian membakar menyan. Dilanjutkan dengan kegiatan berdoa seperti gambar 7 .

Pada gambar 7 kita dapat melihat bahwa peziarah melakukan doa dengan cara merapatkan dua telapak tangan seperti kegiatan sungkem/sembahan. Akulturasi budaya pada proses ini terdapat pada pembakaran dimik dan menyan, sungkem, dan tahlilan. Dimik dan menyan erat kaitannya dengan kebudayaan Hindu-Budha, sungkem erat kaitannya dengan kebudayaan kejawen, dan tahlilan erat kaitannya dengan budaya Islam.

Akulturasi kebudayaan lainnya ditemukan pada kesenian yang berkembang di area sekitar makam.

Kesenian yang berkembang di area sekitar makam adalah kesenian hadroh kontemporer. Hadroh yang diracik sede-

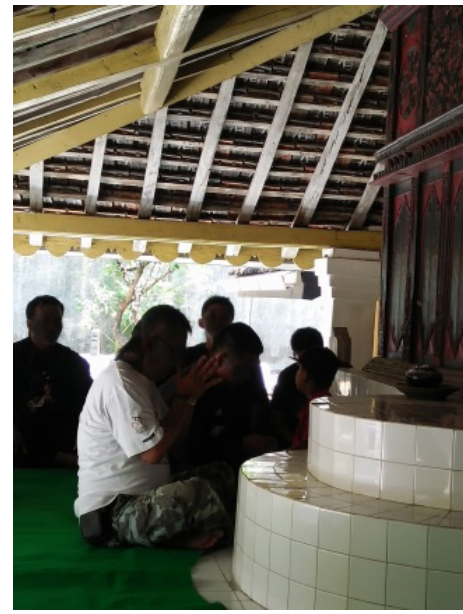

Gambar 7. Peziarah yang sedang berdoa (Dok. Amirul, 2017)

mikian rupa disesuaikan dengan modernitas zaman. Seni musik hadroh tentunya erat berkaitan dengan kebudayaan Islam yang berasal dari Timur Tengah. Hadroh kontemporer merupakan gabungan dari instrumen hadroh dasar digabungkan dengan instrumen modern misalnya piano, kendang ketipung, dll. Hal ini tentunya menimbulkan akulturasi budaya antar kebudayaan.

Kesenian di sekitar makam tidak hanya hadroh saja melainkan ada kesenian lain yang bernama Jemblung. Seni Jemblung merupakan perpaduan antara kebudayaan asli Ponorogo yaitu Reog dengan kebudayaan lainnya. Gamelan Reog dimodikasi digabungkan dengan perangkat karawitan lainnya. Hasil modifikasi ini kemudian dibunyikan untuk mengiringi pentas Jemblung. Jemblung dimainkan oleh seorang Dalang. Dalang akan mementaskan pertunjukan drama menggunakan media wayang. Perbedaan besar gamelan Reog dan gamelan Jemblung terletak pada modifikasi gong gedhe-nya. Modifikasi ini bertujuan untuk menghindari penggunaan gong gedhe. Membunyikan gong gedhe di daerah ini merupakan hal yang dilarang. Hal tersebut sesuai dengan data hasil wawancara di bawah ini.

"Reog tidak ada, karawitan tidak ada, disini menabuh gong gedhe reog dan karawitan tidak boleh karena bersebelahan dengan makam. Adanya hadroh kontemporer di RT 3/ RW 1. Di sini adanya jemblung. Ceritanya seperti wayang golek. Gongnya dimodifikasi dikasih plat di tengahnya. Suaranya tetap menggema. Modifikasi peralatan reog untuk menghindari penggunaan gong besar. Jemblung ini menceritakan drama. Jemblung di RT 1/ RW 2 Krajan. Di sini ada 16 RT dan 4 RW."

Menurut penuturan informan di atas, daerah di sekitar makam Bathara Katong dihindari untuk menggunakan gong besar dan menyelenggarakan pentas Reog. Hal ini dipercayai sebagai bentuk penghormatan terhadap Bathara Katong beserta Sentono nDalem yang dikebumikan di 
daerah tersebut. Masyarakat menyiasati dengan menciptakan jenis kesenian baru yang merupakan perpaduan dari kesenian yang telah ada dengan kreatifitas yang didasari modernitas zaman.

\section{SIMPULAN}

Akulturasi budaya diakibatkan oleh adanya perbedaan antara kebudayaan asal dengan kebudayaan asing yang datang. Lambat laun kedua kebudayaan itu kemudian saling berterima. Proses perpaduan antara dua kebudayaan inilah yang membentuk kebudayaan baru tanpa menyebabkan hilangnya kepribadian kebudayaan asalnya. Proses akulturasi ini tentunya membutuhkan waktu yang tidak sebentar. Akulturasi budaya pada tradisi ziarah makam Bathara Katong dapat ditemukan pada bangunan-bangunan yang ada di area makam Bathara Katong, pada benda-benda yang dibawa oleh peziarah, pada proses tradisi, serta pada kesenian yang berkembang di area sekitar makam.

\section{DAFTAR RUJUKAN}

Anggrahita, N. H dan Sunarto. (2016). Kesenian Laesan di Kecamatan Lasem Kabupaten Rembang (Kajian Fungsi dan Konflik). Jurnal Catharsis Volume 5 No. 1 Halaman 9-17.

Arifin, Z. (2011). Penelitian Pendidikan. Bandung: PT. Remaja Rosdakarya.

Bayuadhy, G. (2015). Tradisi-tradisi Adiluhung Para Leluhur Jawa. Yogyakarta: Dipta.

Koentjaraningrat. (2009). Pengantar Antropologi I. Jakarta: PT. Rineka Cipta.

Koentjaraningrat. (1984). Kebudayaan Jawa. Jakarta: PN Balai Pustaka.

Macaryus, Sudartomo. 2007. Sengkalan : Tinjauan Struktur dan Isi. Jurnal Sintesis Volume 5 No.2 Halaman 187204.

Muhadjir. (2002). Metode Penelitian Kualitatif IV. Yogyakarta: Rake Sarasin.

Moelyadi. (1986). Ungkapan Kerajaan Wengker dan Reyog Ponorogo. Ponorogo: DPC Pemuda Panca Marga.

Pradanda, W. S, Sudardi, B, Subiyantoro, S. 2015. Kajian Nilai-Nilai Budaya Jawa dalam Tradisi Bancaan Weton di Kota Surakarta (Sebuah Kajian Simbolisme dalam Budaya Jawa). Jurnal Lingua Volume 12 No. 2 Halaman 152-174.

Rahmat, P. S. (2009). Penelitian Kualitatif. Jurnal Equilibrium, 5 (9), 1-8.
Sarosa, S. (2012). Penelitian Kualitatif: Dasar-dasar. Jakarta Barat : PT. Indeks.

Soekanto, S. (1990). Sosiologi Suatu Pengantar. Jakarta: PT Raja Grafindo Persada.

Sulasman dan Setia Gumilar. (2013). Teori-teori Kebudayaan. Yogyakarta: CV Pustaka Setia.

Sutopo, H.B. (2002). Metodologi Penelitian Kualitatif. Surakarta: UNS Press.

Suwito, Yuwono Sri. 2006. Misteri Sengkalan Memet ing Karaton Ngayogyakarta Hadiningrat. Djaka Lodang. No. 20-22. Yogyakarta: PT Djaka Lodang Pers.

Toha, Muchammad. (2016). Kontestasi Pandangan Elite Agama di Gresik tentang Nyekar di Desa Surowiti Kecamatan Panceng. Teosofi: Jurnal Tasawuf dan Pemikiran Islam Vol. 6 No. 1.

Zarifa, A. P. (2017). Masjid dan Makam Sendang Duwur: Perwujudan Akulturasi. Prosiding Seminar Heritage IP$L B I$. 